\title{
Age and Origin of Eclogitic Diamonds from the Jwaneng Kimberlite, Botswana
}

\author{
Richardson, S.H. ${ }^{1}$, Chinn, I.L. ${ }^{1}$, and Harris, J.W. ${ }^{2}$
}

1. Department of Geological Sciences, University of Cape Town, Rondebosch 7700, South Africa
2. Department of Geology and Applied Geology, University of Glasgow, Glasgow G12 8QQ, UK

The 240 Ma old Jwaneng DK2 kimberlite in southern Botswana, probably the most profitable diamond mine in the world, is otherwise notable in several respects. First, the kimberlite carries two generations of kimberlitic zircon, one equivalent to the age of emplacement and the other Archaean (Kinny et al, 1989). Second, a significant proportion of the diamonds are polycrystalline aggregates (Kirkley et al, 1994) as well as cubic or fibrous forms with micro inclusions representing mantle fluids (Schrauder et al, 1996). Third, the majority of macro inclusion bearing diamonds are eclogitic (Gurney et al, 1995) with a wide $\delta^{13} \mathrm{C}$ range from -4 to $-19 \%$ and significantly aggregated nitrogen (Deines et al, 1997).

Previous work on dating eclogitic diamonds from Jwaneng has involved the ${ }^{40} \mathrm{Ar}-{ }^{39} \mathrm{Ar}$ laser probe method applied to clinopyroxene inclusions (Burgess et al, 1992). Minimum individual ages for a set of six cleaved diamonds range from $230 \pm 40 \mathrm{Ma}$ to $420 \pm 90 \mathrm{Ma}$, with a minimum overall age of $240 \mathrm{Ma}$, equivalent to that of kimberlite emplacement. Conversely, the maximum individual age recorded is $1890 \pm 450 \mathrm{Ma}$ ( $2 \sigma$ errors; total age data in Table 1 of Burgess et al, 1992). While these diamonds are clearly xenocrysts in the host kimberlite, partial retention of radiogenic argon diffusing to the inclusion-diamond interface during mantle storage results in an apparent spread of ages converging on that of kimberlite emplacement (Burgess et al, 1992). Here we report Sm-Nd and $\mathrm{Rb}-\mathrm{Sr}$ isotope data for a more extensive suite of eclogitic garnet and clinopyroxene inclusion bearing diamonds from Jwaneng with a view to constraining their age and origin.

Orange garnet and bluish-green clinopyroxene inclusions were extracted from separate sets of one hundred monomineralic inclusion bearing diamonds selected from the $-6+5$ diamond sieve fraction (1.8-2.2 $\mathrm{mm}$ diameter) of mine production. Rare bimineralic inclusion pairs revealed by breaking were set aside for temperature determination. In addition, one large clinopyroxene inclusion was extracted from a 2 carat stone. The garnet inclusions are on average twice as large as their clinopyroxene counterparts. The major element composition of a tiny fragment of garnet and clinopyroxene was determined by electron microprobe, leaving the bulk for isotope analysis.

The garnets are pyrope almandines with a range in $\mathrm{Mg}$ content and a strong clustering around py34al40gr26 (Fig 1) consistent with the data set in Deines et al (1997). The clinopyroxenes are omphacites with a more restricted range in $\mathrm{Mg}$ content and a clustering around wo43en $42 \mathrm{fs} 15$. Garnets and clinopyroxenes with higher $\mathrm{Mg}$ contents are generally paler in colour. Compositional data for the garnet and clinopyroxene pairs mentioned above are reported in Table 1 and illustrated in Fig 2. Equilibration temperatures derived from the Ellis \& Green (1979) thermometer at $50 \mathrm{kbar}$ cluster in the range $1100-1160^{\circ} \mathrm{C}$, again consistent with those reported in Deines et al (1997).

Garnets $(n=47)$ and clinopyroxenes $(n=49)$ with compositions lying in the clusters in Fig. 1 were grouped into composites ( 2.3 and $1.2 \mathrm{mg}$ respectively) to obtain sufficient material for isotope analysis. Large clinopyroxene J201 (Fig 2) was analysed as a single inclusion (1.1 mg). The garnet and clinopyroxene composites define a two-point $\mathrm{Sm}-\mathrm{Nd}$ isochron age of $1540 \mathrm{Ma}$ with a nominal error of $\pm 20 \mathrm{Ma}$ based on in-run precision $\left(2 \sigma_{\text {mean }}\right)$ and an initial ratio $\left(\varepsilon_{\mathrm{Nd}}=+1.0\right)$ indicative of a mildly trace-element depleted precursor. This compares with a Nd model age of $1560 \mathrm{Ma}$ for the garnet composite alone. Pairing of the garnet composite with the single clinopyroxene inclusion gives a significantly younger age $(1320 \mathrm{Ma})$ but unreasonably high initial ratio $\left(\varepsilon_{\mathrm{Nd}}=+10.2\right)$. Overall, the data overlap those for equivalent diamonds from the 120 Ma old Finsch kimberlite in the northern Cape which gave a Sm-Nd sochron age of $1580 \pm 50 \mathrm{Ma}$ and initial ratio $\left(\varepsilon_{\mathrm{Nd}}=+6.7\right)$ 
indicative of a significantly depleted source (Richardson et al, 1990). However, Sm-Nd isochron age interpretation and error assessment are complicated by potential initial ratio variations between samples. In particular, the Jwaneng samples have different $\mathrm{Sr}$ isotope ratios, with a range similar to that for their Finsch counterparts (Richardson et al, 1990; Smith et al, 1991). Measured inclusion ${ }^{87} \mathrm{Sr} /{ }^{86} \mathrm{Sr}$ ratios are comparable to initial ratios at the time of encapsulation by diamond because of low intrinsic $\mathrm{Rb}$ contents and relatively small age corrections. The Jwaneng garnet composite, which has the lowest $\mathrm{Sr}$ concentration $(3.4 \mathrm{ppm})$, has the most radiogenic $\mathrm{Sr}$ isotope composition (0.7117) while the clinopyroxene composite with the highest $\mathrm{Sr}$ concentration $(225 \mathrm{ppm})$ is the least radiogenic (0.7042). Values for the single clinopyroxene inclusion (171 ppm; 0.7050) indicate that the composites may be averaging a significant spread of initial ratios. Furthermore, mixing of depleted (low $\mathrm{Rb} / \mathrm{Sr}$, high $\mathrm{Sm} / \mathrm{Nd}$ ) and enriched (high $\mathrm{Rb} / \mathrm{Sr}$, low $\mathrm{Sm} / \mathrm{Nd}$ ) precursor components is suggested by this spread. Fortunately, radiogenic $\mathrm{Sr}$ is generally correlated with unradiogenic $\mathrm{Nd}$ in enriched continental mantle components, such that the relative spread in initial Nd isotope ratios of individual inclusions comprising the composites may be far smaller than that for $\mathrm{Sr}$ isotopes. Clearly, further work on the largest available non-touching garnet and clinopyroxene inclusion pairs from individual diamonds is warranted to demonstrate isotope equilibrium or otherwise on a single diamond scale, characterise initial ratio variation between diamonds and elucidate overall isochron relationships.

Nevertheless, the similarity in age and geochemical character of eclogitic diamond crystallization at Jwaneng and Finsch is striking and suggests a regional eclogitic diamond formation event on the west side of the Kaapvaal craton in the middle Proterozoic. At both localities, there is substantial evidence that eclogitic diamond formation involved both depleted and enriched components. This supports an origin related to interaction of subducted Proterozoic lithosphere derived melts with Archaean cratonic lithosphere.

\section{References}

Burgess, R., Turner, G., and Harris, J.W., 1992, ${ }^{40} \mathrm{Ar} /{ }^{39} \mathrm{Ar}$ laser probe studies of clinopyroxene inclusions in eclogitic diamonds: Geochim. Cosmochim. Acta 56, 389-402.

Deines, P., Harris, J.W., and Gurney, J.J., 1997, Carbon isotope ratios, nitrogen content and aggregation state, and inclusion chemistry of diamonds from Jwaneng, Botswana: Geochim. Cosmochim. Acta 61, 3993-4005.

Ellis, D.J. and Green, D.H., 1979, An experimental study of the effect of calcium upon garnetclinopyroxene iron-magnesium exchange equilibria: Contrib. Mineral. Petrol. 71, 13-22.

Gurney, J.J., Harris, J.W., Otter, M.L., and Rickard, R.S., 1995, Jwaneng diamond inclusions: Extended Abstr., 6IKC, Novosibirsk, 208-210.

Kinny, P.D., Compston, W., Bristow, J.W., and Williams, I.S., 1989, Archaean mantle xenocrysts in a Permian kimberlite: two generations of kimberlitic zircon in Jwaneng DK2, southern Botswana. In: Ross, J. et al. (eds) Kimberlites and Related Rocks. Geol.Soc. Australia Spec. Publ. 14, 833-842. Kirkley, M.B., Gurney, J.J., and Rickard, R.S., 1994, Jwaneng framesites: carbon isotopes and intergrowth compositions. In: Meyer, H.O.A. and Leonardos, O.H. (eds) Diamonds: Characterization, Genesis and Exploration. CPRM Spec. Publ. 1/B, 127-135.

Richardson, S.H., Erlank, A.J., Harris, J.W., and Hart, S.R., 1990, Eclogitic diamonds of Proterozoic age from Cretaceous kimberlites: Nature 346, 54-56.

Schrauder, M., Koeberl, C., and Navon, O., 1996, Trace element analyses of fluid-bearing diamonds from Jwaneng, Botswana: Geochim. Cosmochim. Acta 60, 4711-4724.

Smith, C.B., Gurney, J.J., Harris, J.W., Otter, M.L., Kirkley, M.B., and Jagoutz, E., 1991, Neodymium and strontium isotope systematics of eclogite and websterite paragenesis inclusions from single diamonds, Finsch and Kimberley Pool, RSA: Geochim. Cosmochim. Acta 55, 2579-2590. 


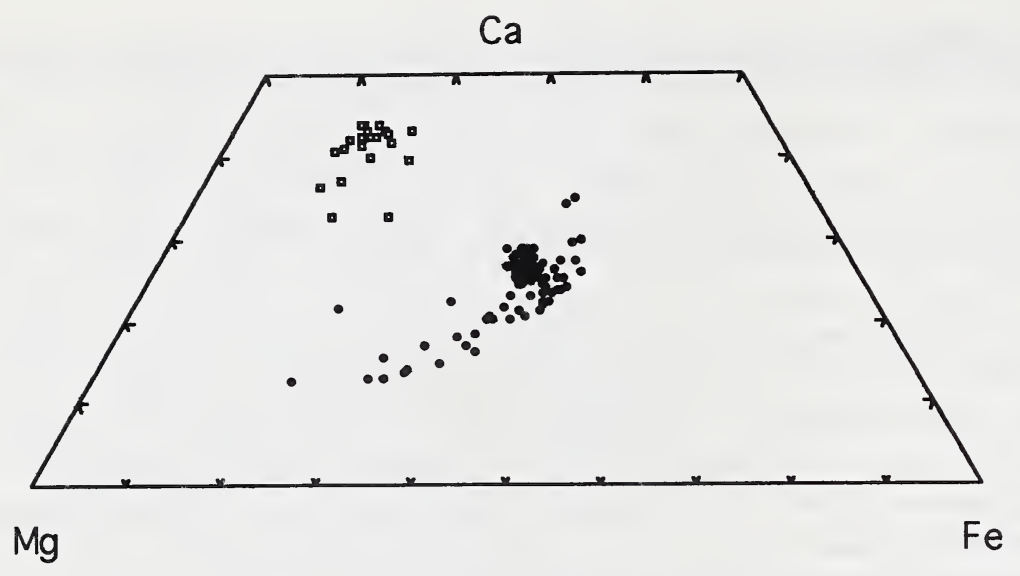

Fig.1. Composition of garnet $(n=96)$ and clinopyroxene $(n=22)$ inclusions from Jwaneng.

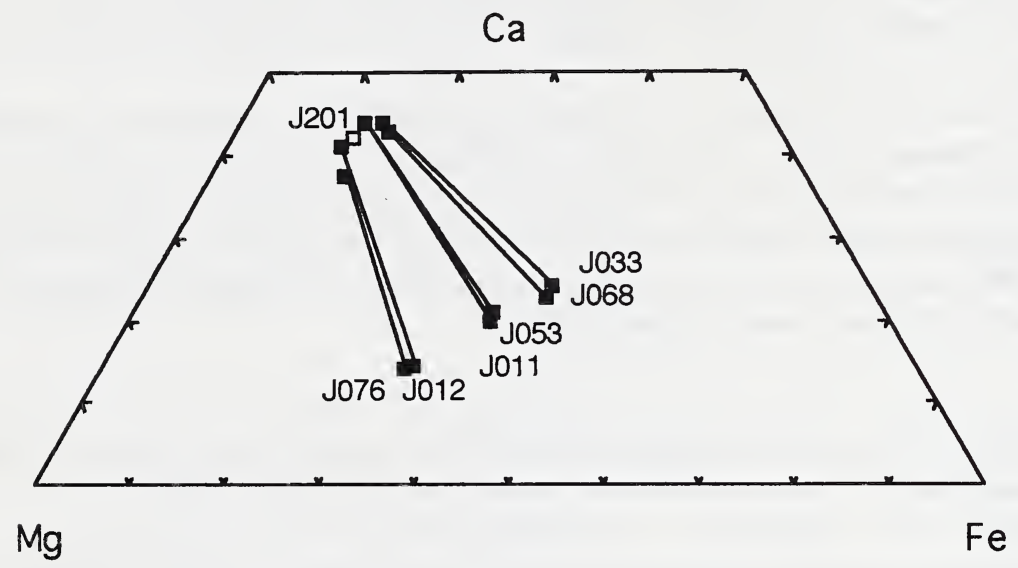

Fig. 2. Composition of coexisting garnet and clinopyroxene inclusions from Jwaneng. The open symbol represents clinopyroxene $\mathrm{J} 201$ analysed separately for isotopic composition.

Table 1 Representative analyses of coexisting garnet and clinopyroxene inclusions.

\begin{tabular}{|c|c|c|c|c|c|c|c|c|c|c|c|c|}
\hline & \multicolumn{2}{|c|}{ J011 } & \multicolumn{2}{|c|}{$\mathrm{J} 012$} & \multicolumn{2}{|c|}{$\mathrm{J} 033$} & \multicolumn{2}{|c|}{ J053 } & \multicolumn{2}{|c|}{ J068 } & \multicolumn{2}{|c|}{ J076 } \\
\hline & gt & cpx & gt & cpx & gt & cpx & $\mathrm{gt}$ & cpx & gt & cpx & gt & cpx \\
\hline $\mathrm{SiO}_{2}$ & 39.66 & 55.33 & 40.24 & 55.36 & 39.85 & 53.90 & 39.68 & 54.10 & 39.48 & 55.00 & 41.06 & 53.58 \\
\hline $\mathrm{TiO}_{2}$ & 0.40 & 0.41 & 0.27 & 0.56 & 0.44 & 0.52 & 0.72 & 0.79 & 0.57 & 0.64 & 0.42 & 0.20 \\
\hline $\mathrm{Al}_{2} \mathrm{O}_{3}$ & 22.14 & 9.75 & 23.03 & 8.73 & 22.43 & 9.39 & 21.05 & 7.83 & 21.46 & 9.52 & 21.08 & 4.10 \\
\hline $\mathrm{Cr}_{2} \mathrm{O}_{3}$ & 0.05 & 0.07 & 0.06 & 0.06 & 0.05 & 0.06 & 0.07 & 0.08 & 0.04 & 0.06 & 0.24 & 0.14 \\
\hline $\mathrm{FeO}$ & 17.86 & 5.51 & 15.64 & 4.98 & 19.71 & 5.98 & 18.43 & 5.44 & 20.42 & 6.46 & 15.85 & 7.75 \\
\hline $\mathrm{MnO}$ & 0.41 & 0.08 & 0.36 & 0.09 & 0.37 & 0.07 & 0.34 & 0.03 & 0.42 & 0.08 & 0.33 & 0.12 \\
\hline $\mathrm{MgO}$ & 11.08 & 9.99 & 14.38 & 11.28 & 8.72 & 9.21 & 11.14 & 10.24 & 9.22 & 9.24 & 14.76 & 14.65 \\
\hline $\mathrm{CaO}$ & 7.47 & 14.30 & 5.34 & 13.51 & 8.85 & 13.78 & 7.76 & 14.52 & 8.37 & 13.70 & 5.23 & 15.64 \\
\hline $\mathrm{Na}_{2} \mathrm{O}$ & 0.17 & 5.23 & 0.13 & 5.17 & 0.17 & 5.74 & 0.26 & 4.82 & 0.20 & 5.37 & 0.12 & 2.39 \\
\hline $\mathrm{K}_{2} \mathrm{O}$ & n.a. & 0.10 & n.a. & 0.08 & n.a. & 0.07 & n.a. & 0.34 & n.a. & 0.14 & n.a. & 0.19 \\
\hline Total & 99.24 & 100.77 & 99.45 & 99.82 & 100.59 & 98.72 & 99.45 & 98.19 & 100.18 & 100.21 & 99.09 & 98.76 \\
\hline $\mathrm{mg}^{\#}$ & 53 & 76 & 62 & 80 & 44 & 73 & 52 & 77 & 45 & 72 & 62 & 77 \\
\hline
\end{tabular}

